\title{
Effect of oil pollution on serum growth hormone (GH) levels, histology and Ultrastructure of muscles of the Nile Tilapia (Oreochromis niloticus)
}

\author{
Abdallah A. El-Shebly ${ }^{1}$ and Heba Allah M. Elbaghdady ${ }^{2}$ \\ 1- National Institute of Oceanography and Fisheries, Alexandria, Egypt \\ 2-Zoology Department, Faculty of Science, Mansoura University, Egypt
}

\begin{abstract}
$\mathrm{O}$ ver the last decades, there has been a growing interest in studying the main problems that could be harmful to the River Nile system in Egypt. Attention was paid to one of the most important problems that face the River Nile, this is called River Nile transport project. So the main objective of the present study was to investigate the adverse effects that can result from spilled gasoline as petroleum product from various motor ships into the River Nile on one of the most important popular fishes in Egypt, Oreochromis niloticus to ascertain whether spilled gasoline into aquatic ecosystems can affect on the aquatic biota or not and to identify any potential public health risks that can be associated with dietary intake of such fish by histological and ultrastructural studies on its edible muscles. Levels of the growth hormone secreted by the pituitary gland which is essential to the development of skeletal muscles and growth rate was also examined. So, the fish were exposed to increasing concentrations of gasoline: 0 (control), 100, 200 and $500 \mathrm{mg} / \mathrm{L}$ for 30 days. Unexposed fish exhibited significantly higher levels of serum $\mathrm{GH}$ compared to that of tested fish. The GH levels decreased significantly with increasing gasoline concentrations. These data together indicate that Gasoline presents a hazardous substance for both the fish as well as the human consumers . Finally, the results revealed that the River Nile transport project can lead to serious harm to fish community that eventually become unsafe for human consumption. Therefore, this project must be carefully revised forbidden by health agencies.
\end{abstract}

Keywords: gasoline, Nile tilapia, histopathology, ultrastructure, growth hormone (GH).

\section{INTRODUCTION}

Quality of aquatic environment is considered the main factor controlling the state of health and disease for both humans and animals. Furthermore, the River Nile is the principal fresh water resource in Egypt, meeting nearly all demands required for drinking water, irrigation and industry. So, pollution of the River Nile constitutes a major concern for the whole country that should be taken into consideration to protect it from any form of pollution (Ali and Soltan, 1996). In the last years, environmental oil pollution by different petroleum compounds has long been recognized as a serious public health problem that 
represents great risk for aquatic environment (Anwar, 2003). In fact, this problem is concerned with the pollution resulting from accidental spillage of gasoline from fishery boats that have been noticed to increase year by year. This has periodically attracted national and international attention in the last few years. Detection of toxic compounds in the aquatic environment and evaluation of their effect on fish is a basic issue in aquatic toxicology (Datta and Kaviraj, 2003).

Gasoline was estimated to be one of the most important elements that have severe toxic impacts on aquatic organisms. This compound can find its way into water from boats, oil drilling rigs, oil refineries, automobile service stations and streets. In the aquatic environment, this hydrocarbon is easily taken up by aquatic organisms and strongly accumulated in their tissues (Talat and Maha, 1999; Regina et al., 2007). Gasoline bioaccumulation by aquatic organisms has been the subject of considerable interest in the recent years, since high levels of gasoline can have serious effects on aquatic organisms and may create problems in relation to their suitability as food for humans (McGrath et al., 2005 and Jemmla et al., 2006). The response of fish to such environmental challenges is ultimately reflected as overall alteration in metabolism. These responses are initially reversible, but prolonged exposure to environmental pollutants brings about permanent (pathological) changes in fish physiology. The alterations are reflected as reduced survival potential, inhibited growth (Figueiredo-Fernandes et al., 2007), reproductive dysfunction (Tyler et al., 1998) and immune suppression (Fatima et al., 2000, 2001).

In this concern, Nile tilapia was the fish chosen for gasoline test application because this fish is considered as one of the most commercially important fresh water fish species of Cichlidae in aquaculture today in Egypt (Alne-na-ei, 1998, Soliman et al., 2004). In addition, it is relatively cheap source of animal protein and the most popular one (Biswas et al., 2004). In the light of this concern and the pollution that is the River Nile facing, questions have been raised about the safety of eating fishes from River Nile water. Therefore, the present study was carried out to investigate the contaminating effect resulted from oil pollution by water soluble fractions of gasoline on Oreochromis niloticus through the determination of observed alterations in muscles by histological and ultrastructural techniques and also its effect on serum growth hormone levels and accordingly on fish yield and for feeding safety and to determine the possible relationship between Nile pollution and the overall fish biology.

\section{Experimental animals}

\section{MATERIALS AND METHODS}

Nile tilapia (Oreochromis niloticus) of both sexes with an average weight of $(150 \pm 4.8 \mathrm{~g}$ and length of $20.87 \pm 1.7 \mathrm{~cm})$ were acquired from a private farm and acclimated to laboratory conditions in declorinated tap water under natural photoperiods (12h light $-12 \mathrm{~h}$ dark) for 15 days. Water was 
oxygen saturated through constant aeration in a static system. Water quality parameters were as follow: temperature $\left(22 \pm 0.5{ }^{\circ} \mathrm{C}, \mathrm{pH} 7.6 \pm 0.1\right.$, dissolved oxygen $7.3 \pm 0.4 \mathrm{mg} / \mathrm{L}$, un-ionized ammonia $0.007 \pm 0.001 \mathrm{mg} / \mathrm{L}$, nitrite $0.02 \pm$ $0.005 \mathrm{mg} / \mathrm{L}$ and alkalinity $73 \pm 5.5 \mathrm{mg} / \mathrm{L} \mathrm{CaCO} 3)$. All water parameters were determined according to APHA (American Public Health Association, 1992). Fish were fed daily with commercial fish pellets where feces and pellet residues were removed daily by suction. After the acclimation, fish were assigned to treatments in 12 glass aquaria $(60 \mathrm{~L}$ each) with a density of 10 fishes/ aquarium as four groups (three replicates per treatment). The first group was kept as control (untreated fish). The other three groups (2, $3 \& 4)$ were exposed to 100 , 200 , and $500 \mathrm{mg} / \mathrm{L}$ gasoline respectively for 30 days under controlled laboratory conditions. Dead fish were counted and removed immediately. Aeration and water quality did not change throughout the experimental period and remained within the optimal values described above. The fish were fed once daily for one month with suitable commercial fish-food throughout the experiment.

Composition and approximate chemical analysis of the experimental diet:

Ingredients

Rice bran

Yellow corn

Soybean meal (44\% cp.)

Fish meal

Meat meal

Molasses

Total

\section{Dissection of animals}

At the end of exposure, fishes were randomly selected from the control group and tested groups and transported in well-aerated containers in the laboratory for preparation of specimens for light microscopic and ultrastructural studies. Blood was collected from the caudal vein, centrifuged at $3000 \mathrm{rpm}$ for 15 minutes to obtain serum, and stored at $-20{ }^{\circ} \mathrm{C}$ until analysis. The analysis for $\mathrm{GH}$ serum levels in all experimental groups was performed by a private medical laboratory.

\section{Histological studies and histopathology}

For histopathological preparations, five fishes from the control and gasoline exposed groups were dissected carefully and muscles were removed immediately to avoid autolysis. They were cut into approximately $0.5 \mathrm{~cm}^{3}$ pieces and fixed in 10\% buffered-neutral formalin for 24 hours (Bancroft and Stevens, 1990). Fixed specimens were dehydrated in graded ethanol concentrations $(50 \%$, $70 \%, 80 \%, 95 \%$ and absolute ethyl alcohol) for 30 minutes each and cleared in xylene solution until they became translucent (two changes each). Tissues were subsequently embedded in molten paraffin wax for one hour to remove xylene completely and to hold the tissues for sectioning (usually one tissue per "block"). Then the blocks were cut in a rotary microtome to prepare sagittal sections of 
thickness 4 to $6 \mu \mathrm{m}$, mounted on acid-washed glass slides. These sections were deparaffinized in xylene, hydrated in ethanol. Then placed on glass slides to be stained with hemotoxylin and eosin (H\&E). At this time changes induced by gasoline addition in these organs were photographed and examined by light microscopy (Roberts, 1978).

Transmission electron microscopy (TEM)

For transmission electron microscopy, small specimens of the skeletal muscles (approximately $1 \mathrm{~mm}$ long) were fixed in $2.5 \%$ glutaraldehyde in $0.1 \mathrm{M}$ sodium cacodylate buffer $(\mathrm{pH}, 7.2)$ for three hours. These specimens were then kept overnight in $0.2 \mathrm{M}$ sodium cacodylate buffer, treated with $1 \%$ osmium tetroxide in $0.1 \mathrm{M}$ sodium cacodylate buffer at 7.2, dehydrated in a graded series of acetone, embedded in Epon-Araldite mixture then ultra-thin sections were stained with uranyl acetate followed by lead citrate (Reynolds, 1963) and examined by Joel Electron Microscope (Japan) operating at $60 \mathrm{KV}$ in Faculty of Science, Alexandria University.

\section{Fish Behavior and Mortality}

\section{RESULTS}

Fish exposed to higher doses of Gasoline concentrations (Groups 2 and 3) of 200 and $500 \mathrm{mg} / \mathrm{L}$ showed clinical signs including rapid respiration, increased rate of gill cover movements, decreased reflex responses and swimming movements, gasping for oxygen at the surface of water and rapid random movements in the aquaria. The mucous secretion increased and accumulated on the gills. Hemorrhagic patches appeared on the ventral surface of the fish with general discoloration and anoxia. Mortality rate of fishes from tested groups was higher compared to control fishes. In addition, death of Oreochromis niloticus exposed to $100 \mathrm{ppm}$ was first reported on the fifth day post exposure and then increased steadily until termination of the test at day 30 . It was noticed that fish exposed to $200,500 \mathrm{ppm}$ were the most affected.

\section{Histological studies on muscles}

Toxicity of water soluble fractions of gasoline to fishes was exhibited by histological and ultrastructural studies of muscles in specimens of tilapia exposed to different concentrations of this compound. The histopathological studies on muscles of specimens under the effect of water soluble fractions of gasoline revealed several lesions. The severity of these lesions progressed with increase of gasoline concentration.

\section{1- Control group}

No detectable pathological changes were observed as regards structure of the muscular tissue in control fish, where the muscles had proper structure and striation that were clearly visible. Skeletal muscle was composed of elongated muscle fibers that vary slightly in diameter and grouped together into elongate bundles called fascicule with delicate supporting tissue (endomysium) that occupies the space between the individual muscle fibers. These muscle 
fibers were not grouped at random fashion but were arranged in regular bundles surrounded by the epimysium, an external sheath of dense connective tissue while the connective tissue around each bundle of muscle fibers is called perimysium (Fig. 1).

\section{2- Tested groups}

After exposure to water soluble fractions of gasoline at different concentrations, muscles showed marked signs of degenerative changes as follows:

\section{(a) Exposure to $100 \mathrm{ppm}$ gasoline}

After exposure to $100 \mathrm{ppm}$ gasoline, the fish muscles showed atrophy in muscles bundles. In addition, muscle fibers appeared relaxed in some regions while many fibers terminated by pointed ends distinguished by wide extracellular spaces occupied by connective tissue (Fig. 2).

\section{(b) Exposure to 200 ppm gasoline}

After exposure to 200 ppm gasoline, muscle fibers appeared relaxed in some regions while many fibers terminated by pointed end and distinguished by wide extracellular spaces occupied by connective tissue (Fig. 3). It was also noticed that degenerated muscle fibers were accompanied with focal area of necrosis (myolysis).

\section{(c) Exposure to 500 ppm gasoline}

After exposure to $500 \mathrm{ppm}$ gasoline, muscle fibers appeared relaxed. In other instances, many muscle fibers terminated by pointed end in addition to presence of focal area of necrosis (Fig. 4).

\section{Ultrastructural studies of muscles}

\section{1- Control fish}

Regarding ultrastructural observations of skeletal muscular tissue of control fish, they showed regular sarcomeres, with pronounced striations. Also symmetric and parallel myofibril distribution was observed. Ultrastructure of myofibres consists of delicate myofilaments. Ultrastructural observations showed also that A-band, H-band, I-band and $\mathrm{Z}$ line were clearly visible in regular arrangement. In the intermyofibril spaces, broad junctions of smooth sarcoplasmatic reticulum of varying sizes, shapes and densities were noticeable (Figs. 5, 6). Mitochondria of different sizes, shapes and numbers are concentrated in groups immediately beneath the sarcolema. These mitochondria contain slightly or moderately electron-dense matrices.

\section{2- Tested fish}

In comparison to the control group, muscle fibers of fishes exposed to different concentrations of gasoline showed many considerable changes from normal muscles. They appeared small, relaxed, vary in diameter, have obviously degenerated muscle fibers and increased connective tissue. Muscle fibers of tested fishes could be distinguished by wide extracellular spaces occupied by connective tissue and dilated blood capillaries with damaged endothelial cells. Also, vacuolation in the connective tissue cells has been observed. In some 
muscle fibers, distinct myofibrils were not distinguished in longitudinal sections and also the myofibrils in some muscle fibers were not arranged in regular parallel pattern.

In some regions in muscle fibers, discrete and incomplete myofibrils were observed. In all muscle fibers myofibrils appeared relaxed and the I-bands were wide. The $\mathrm{Z}$ lines were thicker than normal and sometimes followed a less regular width of the myofibrils. The myofibrils seem to be separated by interfibrillar area which was clearly wider than control muscle fibers, therefore the myofibrils components appeared reduced, i.e., thin myofibrils were clearly noticed. The interfibrillar sarcoplasm was relatively abundant. The sarcoplasm between the myofibrils contain degenerated sarcoplasmic organelles. In other regions, degenerated myofibrils (atrophied) were observed. In the interfibrillar sarcoplasm numerous profiles of the sarcoplasmic reticulum were less noticed compared with those from control specimens. In some cases, dilation and enlarged canals of sarcoplasmic reticulum were also noticed.

Mitochondria appeared few in the muscles of tested fishes. They have irregular outline and their matrix was filled with numerous electron dense granules. On both sides of $\mathrm{Z}$ strip, disturbances in the myofilaments structure were observed. In these places, myofilaments were irregular, and sometimes totally disappeared. Disintegrated $\mathrm{Z}$ line was also observed in some myofibrils. Furthermore, discrete and incomplete myofibrils were observed in some regions of muscle fibers. In other regions, the myofibrils appeared as spiral-shaped ropes. Finally, it was noticed that disruption and lysis demonstrated in muscle fibers were gasoline concentration dependent.

\section{Levels of serum growth hormone}

The analysis of growth hormone in Oreochromis niloticus exposed to gasoline revealed that the average maximum level of growth hormone $(0.7$ $\mathrm{ng} / \mathrm{ml})$ was recorded in the control group, while the average minimum level $(0.2$ $\mathrm{ng} / \mathrm{ml}$ ) was recorded for group 4 (500 mg gasoline/L) (Table. 1).

Table 1: Changes in serum GH levels of O. niloticus exposed to different concentrations of gasoline under laboratory conditions:

\begin{tabular}{|l|l|l|}
\hline Tested groups & Gasoline concentrations & GH levels (ng/ml) \\
\hline Control & Without gasoline & 0.7 \\
\hline 1 & $100 \mathrm{mg} / \mathrm{L}$ & 0.5 \\
\hline 2 & $200 \mathrm{mg} / \mathrm{L}$ & 0.4 \\
\hline 3 & $500 \mathrm{mg} / \mathrm{L}$ & 0.2 \\
\hline
\end{tabular}

\section{DISCUSSION}

Petroleum compounds are considered the most important pollutants present throughout the aquatic ecosystems. They are non-biodegradable and once discharged into water bodies, they can either be adsorbed on sediment particles or accumulated in different organs of aquatic organisms (Abdel- 
Hameid, 2007). Not only does environmental pollution by petroleum compounds caused a decline in water quality but subsequently affects all living organisms in that system. It is therefore necessary not only to identify these pollution sources but also to monitor and manage their effects on the health of aquatic ecosystem (Jiraungkoorskul et al., 2006). Bioconcentration of PAHs from water into fish tissue depends on the balance between uptake and elimination rates (Jonsson et al., 2004).

Aquatic animal health status has been shown to be a useful indicator of water quality. The abnormal behavior of the fish that was observed in response to gasoline exposure could be attributed to the effect of gasoline on central nervous system and cardiovascular system of the fish (Baussant et al., 2001). The bioaccumulation of gasoline may lead to high mortality rate or cause alterations in fish organs (Abdel-Hameid, 2007).

Muscles are one of the most important tissues that have been studied under the effect of gasoline as it comes also into close contact with dissolved pollutants and toxins in water (Goldspink et al., 2001; Sanger and Stoiber, 2001). The muscular tissue constitutes from one-third to one-half of the body mass of the average vertebrate and represents about $60 \%$ of the total fish body mass (Srivastava et al., 2009). Muscle tissue performs many of the vital functions such as locomotion through its direct connection with the skeletal system causing balanced swimming and helps to generate heat due to catabolic reactions that are associated with muscular activity and prevents movement of body by opposing forces. In addition, this tissue is the most edible part preferred by consumers in the fish. Thus it was the focus of the present study.

All muscle tissues consist of muscle fibers, each contains numerous microfibrils made of two types of contractile protein filaments: actin and myosin. Myosin is the most abundant protein in the muscle tissue (the myofibril) occurring chiefly in A band; with actin it forms actomyosin, which is responsible for the contractile properties of muscles as it produces the force for muscular contraction. These contractile filaments (actin and myosin) form distinct crossstriations which are seen under the microscope as light I bands and dark A bands across each muscle fiber (El-Rawi and Yousif, 2007).

In the present study, muscles of the tested specimens exhibited degeneration in muscle bundles accompanied with focal areas of necrosis, as well as, atrophy and vacuolar degeneration in some muscle bundles. There was no arrangement of muscle bundles. Also many muscle fibers terminated by a pointed end distinguished by wide extracellular space that is occupied by connective tissue. In spite of the fact that a given gasoline dose is tolerated by fish, it causes many alterations that produce loss of balance during swimming behavior in tested fishes. This agrees with the deleterious effects shown in muscle ultrastructure caused by a common herbicide on the fish Colossoma macropomum (Medina and Urbina, 1992). Moreover, degeneration in muscle bundles was accompanied with focal areas of deep myolysis. Also splitting 
muscle fibers, atrophy and vacuolar degeneration in muscle bundles were among the most common alterations that were observed due to gasoline accumulation. The present findings are in agreement with Hernandez et al. (2005) on their study on pesticides. They attributed such differences in feeding and swimming performance to architectural differences in musculoskeletal design and basic cytoarchitectural differences within individual muscles.

\section{REFERENCES}

Abdel-Hameid, N. H. (2007): Physiological and histopathological alterations induced by phenol exposure in Oreochromis aureus juveniles. Turkish J. Sc., 7: 131-138.

Ali, M. M. and Soltan, M. E. (1996): The impact of three industrial effluents on submerged aquatic plants in the River Nile, Egypt. Ecotoxicol. Environ. Saf., 34: 77-83.

Alne-na-ei, A. A. (1998): Morphometric effects of environmental stressors on the gills of the wild freshwater teleost Oreochromis niloticus with particular reference to the physical properties of gill mucus as a Possible measure of water contamination. $8^{\text {th }}$.Int. Conf., J. Egypt. Ger. Soc. Zool., 26(B): 1-24.

Anwar, W. A. (2003): Environmental health in Egypt. Intern J. hyg and env health., 206: 339-350.

APHA (American Public Health Association), (1992): Standard methods for the examination of the water and waste-water including bottom sediments and sludge. $12^{\text {th }}$ Edition, INC $>$ New York, USA, 769pp.

Bancroft, J. D. and Stevens, A. (1990): Theory and practice of histological techniques ed.3, Churchill livingstone inc. Edinburgh. London, Melbourne and New York.

Baussant, T.; Sanni, S. and Jonsson, G. (2001): Bioaccumulation of polycyclic aromatic compounds: 1. Bioconcentration in two marine species and in semi permeable membrane devices during chronic exposure to dispersed crude oil. Env Tox Chem., 20: 1175- 1184.

Biswas, A. k.; Morita, T.; Yoshizaki, G.; Maita, M. and Takeuchi, T. (2004): Control of reproduction in Nile tilapia Oreochromis niloticus (L.) by photoperiod manipulation. Aquacul., 243: 229-239. 
Datta, M. and kaviraj, A. (2003): Acute toxicity of the synthetic pyrethroid deltamethrin to freshwater catfish Clarias gariepinus. Bull. Env. Cont. Tox., 70: 296- 299.

El-Rawi, M. M. and Yousif, W. B. (2007): Electron microscopic studies on the effect of diazepam on mouse Sartorius muscle. Pakistan J. Biol. Sc., 10 (14): 2267-2276.

Fatima, M.; Ahmad, I.; Sayeed, I.; Ather, M. and Raisuddin, S. (2000): Pollutant- induced over-activation of phagocytosis concomitantly associated with peroxidative damage in fish tissues. Aq Tox., 49 (4): 243- 250 .

Fatima, M.; Ahmad, I.; Siddiqui, R. and Raisuddin, S. (2001): Paper and pulp mill effluent-induced immunotoxicity in freshwater fish Channa punctatus (Bloch). Arch. Env. Cont. Tox., 40: 271- 267.

Figueiredo-Fernandes, A.; Ferreira-Cardoso, J. V.; Garcia-Santos, S.; Monteiro, S. M.; Carrola, J.; Matos, P. and Fontainhas-Fernandes, A. (2007): Histopathological changes in liver and gill epithelium of Nile tilapia, Oreochromis niloticus exposed to waterborne copper. Pesq. Vet.Bras., 27(3): 103-109.

Goldspink, G.; Wilkes, D. and Ennion, S. (2001): Myosin expression during ontogeny, post-hatching growth and adaptation. In: Muscle development and growth. Johnston, I.A., Academic Press, Califórnia., 18: 43-72.

Hernandez, L. P.; Patterson, S. E. and Devoto, S. H. (2005): The development of muscle fiber type identity in zebrafish cranial muscles. Anatomy and Embryology j., 209(4): 323-334.

Jemmla, M. T.; Trindade, M.; Marques, A. L.; Lopes, G. S.; Marques, E. P. Zhang, J. (2006): Arsenic determination in gasoline by hydride generation atomic absorption spectroscopy combined with a factorial experimental design approach. Fuel., 85: 2155-2161.

Jiraungkoorskul, W.; Sshaphong, S.; kangwanrangsan, N.; Kim, M. (2006): Histopathological study: the effect of ascorbic acid on cadmium exposure in fish (Puntius altus). J. Fish. Aq. Sc ., 1(2): 191-199.

Jonsson, G.; Bechmann, R. K. Bamber, S. D. (2004): Bioconcentration, biotransformation and elimination of polycyclic aromatic hydrocarbons 
in sheepshead minnows (Cyprinodon variegatus) exposed to contaminated seawater. Env. Tox. Chem., 23:1538-48.

McGrath, J. A.; Parkerton, T. F.; Hellweger, F. L. and DiToro, D. M. (2005): Validation of the narcosis target lipid model for petroleum products: gasoline as a case study. Env. Tox. Chem., 24(9): 2382-2394.

Medina, J. y. and Urbina, H. (1992): Determinación del DL50 con Diquat en ejemplares de Colossoma macropomum, Astronotus ocellatus, Aequiden pulcher. Memorias del VII simposio Latinoamericano de Acuicultura VII Encuentro Venezolano sobre Acuicultura. Barquisimeto, Venezuela., 317-319.

Regina, C. O. B.; Delgado, P.; Antonio, S.; Araujo, N.; Valter, J. and Fernandes, Jr. (2007): Properties of Brazilian gasoline mixed with hydrated ethanol for flex-fuel technology. Fuel Proc Tech., 88: 365-368.

Reynolds, E. S. (1963): The use of lead citrate at high $\mathrm{pH}$ as an electron-opaque stain in electron microscopy. Downloaded from jcb.rupress.org.

Roberts, R. J. (1978): Fish Pathology. Bailliere Tindall Publishers, London.

Sanger, A. M. and Stoiber, W. (2001): Muscle fiber diversity and plasticity. In: "Muscle Development and Growth" (I.A. Johnston, Ed.). Academic Press, Fish Phys Ser., 18: 187-250.

Soliman, M. F. M.; El-Shenawy, N. S. and Ghobashy, M. A. (2004): Parasitological aspects and biochemical changes of infected cultured tilapia (Oreochromis hybrid). Acta Ichthyol. Piscat., 34(1): 21-32.

Srivastava, R.; Srivastavab, S. M.; Abidib, R. and Dasc, M. K. (2009): Cellular level effects of metal toxicity on gills and liver of fishes. Dise. Aqu. Org., 33: 117-125.

Talat, S. and Maha, Al. (1999): Chemical composition of the water soluble fraction of the leaded gasoline in seawater. Env. Intern., 25(1): 117-129.

Tyler, C. R.; Jobling, S. R. and Sumpter, J. P. (1998): Endocrine disruption in wildlife: a critical review of the evidence. Crit. Rev. Toxicol., 28 (4): 319- 361 . 
Fig. 1: Photomicrograph of longitudinal section through the skeletal muscles of Oreochromis niloticus under control conditions showing: Nearly normal histological structure of muscles (EM: endomysium; PM: perimysium; EMF: elongated muscle fibers). (Scale bar represents $200 \mu \mathrm{m}, \mathrm{X} 25$ )

Fig. 2: Photomicrograph of longitudinal section through the skeletal muscles of Oreochromis niloticus after exposure to 100 ppm of gasoline showing: Atrophy of muscle bundles (*), relaxed muscle fibers (RM) in addition to pointed end of muscle fibers $(\mathrm{PE})$ in addition to myolysis and splitting of muscle fibers.

(Scale bar represents $200 \mu \mathrm{m}$, X 25)

Fig. 3: Photomicrograph of longitudinal section through the skeletal muscles of Oreochromis niloticus after exposure to $200 \mathrm{ppm}$ of gasoline showing: Myolysis (arrow), relaxed muscle fibers (RM) and widening in the space between muscle bundles (S) in addition to atrophy of muscle bundles. (Scale bar represents $200 \mu \mathrm{m}, \mathrm{X} 25$ )

Fig. 4: Photomicrograph of longitudinal section through the skeletal muscles of Oreochromis niloticus after exposure to $500 \mathrm{ppm}$ of gasoline showing: High degree of splitting of muscle fibers, myolysis, degeneration in muscle bundles, atrophy of muscle bundles and vacuolar degeneration of muscle bundles (VD).

(Scale bar represents $200 \mu \mathrm{m}, \mathrm{X} 25$ )

Fig. 5: Electron photomicrograph of skeletal muscles of Oreochromis niloticus under control conditions showing A-band (A); I-band (I); H-band (H) and Z-line $(\mathrm{Z})$.

Fig. 6: Electron photomicrograph of skeletal muscles of Oreochromis niloticus under control conditions showing A-band (A); I-band (I); H-band (H); Z-line (Z) and sarcoplasmatic reticulum (RS).

Fig. 7: Electron photomicrograph of skeletal muscles of Oreochromis niloticus after exposure to $100 \mathrm{ppm}$ of gasoline showing irregular coarse of Z-line (head arrow).

Fig. 8: Electron photomicrograph of skeletal muscles of Oreochromis niloticus after exposure to $200 \mathrm{ppm}$ of gasoline showing great myolysis of muscle fibers (ML) and irregular coarse of muscle fibers.

Fig. 9: Electron photomicrograph of skeletal muscles of Oreochromis niloticus after exposure to $200 \mathrm{ppm}$ of gasoline showing irregular pattern of muscle fibers.

Fig. 10: Electron photomicrograph of skeletal muscles of Oreochromis niloticus after exposure to $500 \mathrm{ppm}$ of gasoline showing deep myolysis of muscle fibers (ML).

Fig. 11: Electron photomicrograph of skeletal muscles of Oreochromis niloticus after exposure to $500 \mathrm{ppm}$ of gasoline showing deep myolysis in different myofilament (ML) and complete disappearance of myofilaments in some parts. 

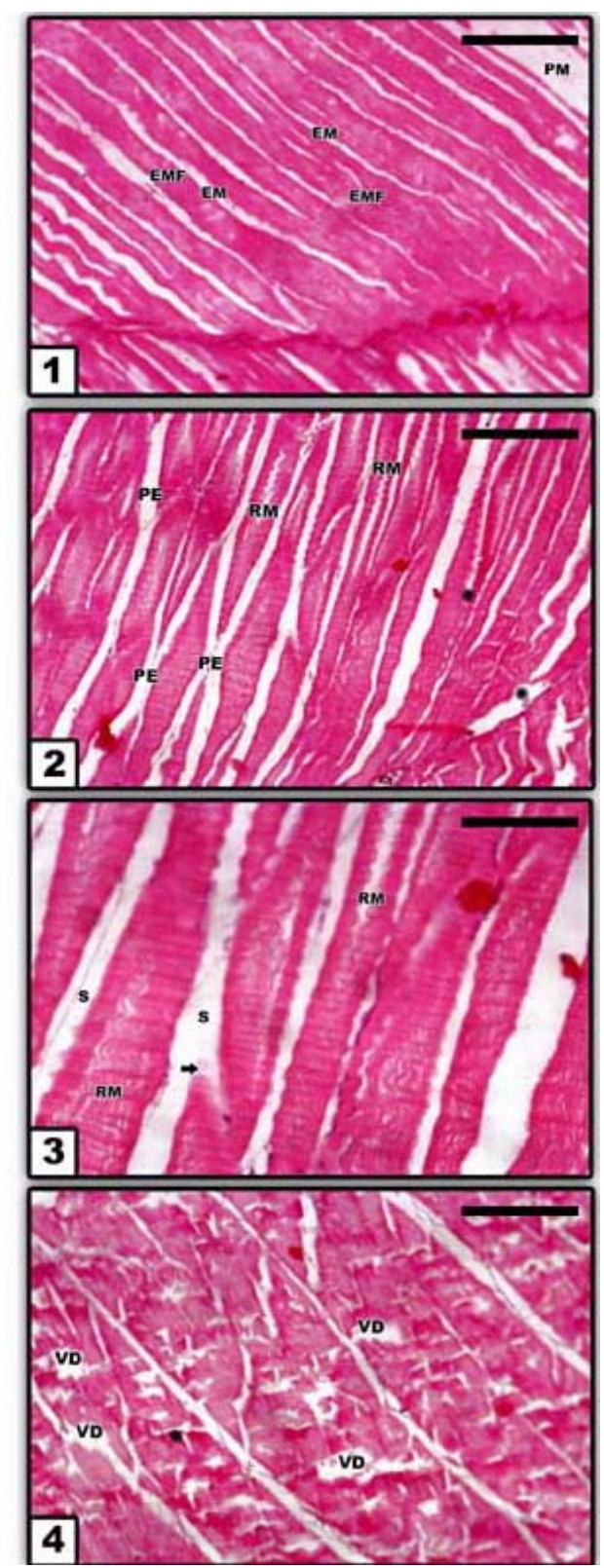


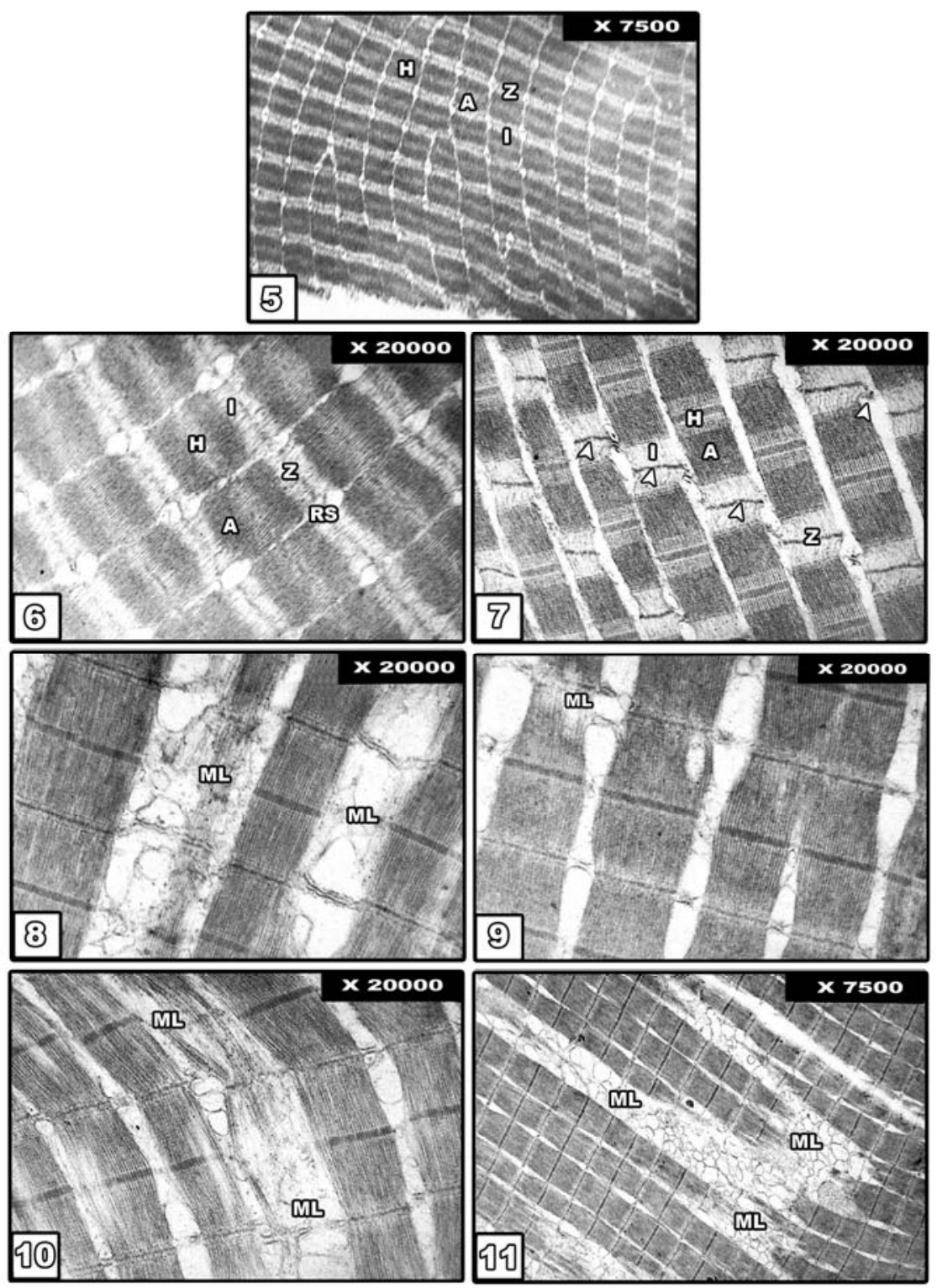

